\title{
Influence of rainfall on tropical coastal artisanal fisheries - a case study of Northern Mozambique *
}

\section{Influência da precipitação nas pescarias artesanais tropicais - o estudo de caso da região norte de Moçambique}

\author{
Antonio Mubango Hoguane ${ }^{\circledR, 1}$, Ezidio da Lucia Cuamba ${ }^{2}$, Tor Gammelsrød ${ }^{3}$
}

\begin{abstract}
The artisanal catch contributed about $87 \%$ of the overall annual marine fish production in Mozambique, estimated to 115,000 $-140,000$ tons, as per fish statistics of the period 2000 and 2004. The availability of most of the coastal marine fisheries depends on a number of factors among which the freshwater input into the coastal waters, either though the rivers or coastal rainfall drainage, as it provides nutrients into the coastal waters that stimulate the primary production. This would enhance the survival and growth of coastal fish species, most of which nurse and breed in estuaries and mangrove swamps. The effect of the freshwater input into the coastal zones through the rainfall $1995-2008$ on the landing of artisanal catches $1998-2008$ in the northern Mozambique (15- $17^{\circ}$ S) was analysed. The results showed that the artisanal annual total catch were significantly correlated to the coastal rainfall lagged two years, with $r=0.7862$ and $p=0.004$. The two-year lag matches the longevity of Engraulididae, Clupeidae and Leiognathidae, and the maturity age of Carangidea, the top four dominant fish families. This result emphasises the role of freshwater in productivity of coastal waters and in the survival and growth rate of the fish population during the earlier stage of their life cycle. The findings in this work may contribute to predict the fish production, and hence improve the management measures of the artisanal fisheries, through setting sustainable fishing quotas. Further, our results contribute to improve our understanding of the climate influence on artisanal fisheries, and so to provide insights of their vulnerability and adaptive capacity to the climate change.
\end{abstract}

Keywords: Coastal rainfall, coastal productivity, fish growth, catch prediction, fisheries management.

\section{RESUMO}

As capturas da pesca artesanal em Moçambique contribuem em cerca de $87 \%$ da captura total anual do país. De acordo com as estatísticas no periodo de 2000 a 2004, as capturas estimadas deste subsector das pescas foram cerca de 115.000 a 140.000 toneladas por ano. A abundância das pescarias marinhas costeiras depende de muitos fatores, dentre os quais a água doce dos rios disponibilizada quer através dos rios ou de águas pluviais drenadas de bacias hidrográficas costeiras, uma vez que providencia nutrientes que fertilizam as águas costeiras, estimulando desse modo a produtividade das mesmas. Isto por sua vez aumenta a sobrevivência e crescimento dos peixes, que na sua maioria crescem e se desenvolvem nos estuários e manguezais. Neste trabalho analisa-se o efeito de água doce, parametrizada por precipitação anual costeira no periodo de 1995 a 2008, nas capturas artesanais nos anos de 1998 a 2008, na zona norte de Moçambique (15० - 17 S). Os resultados indicam haver

@- Corresponding author

1 - School of Marine and Coastal Sciences, Eduardo Mondlane University, PO Box 128, Quelimane, Mozambique.e-mail: hoguane@yahoo.com.br

2 - Pemba Marine Research Centre (CEPAM), P.O.Box 306, Pemba, Mozambique.e-mail:ntchamby@gmail.com

3 - Institute of Geophysics, University of Bergen, Allegt 70, 5007 Bergen, Norway.e-mail: torg@gfinib.no 
uma correlação positiva significativa entre as capturas artesanais anuais e a precipitação costeira anual registada dois anos antes ( $r=0,7862$ e $p=0.004)$. O desfasamento de dois anos entre a precipitação e as capturas está relacionado com o tempo de vida nas famílias Engraulididae, Clupeidae e Leiognathidae e com a idade de maturação na família Carangidea, constituindo estas as principais famílias que compóe as capturas. Estes resultados realçam o papel da água doce drenada para as zonas costeiras na produtividade destas e na sobrevivência e crescimento das populaçôes de peixes durante a fase inicial do seu ciclo de vida. Os resultados deste trabalho podem contribuir para prever as capturas e melhorar a gestão das pescarias artesanais através, por exemplo, de estabelecimento de quotas de pesca em função das previsöes. Mais ainda, as discussóes realizadas contribuem para melhor a nossa compreensão da influência de fatores climáticos nas pescarias artesanais e avançar sugestóes sobre a sua vulnerabilidade e capacidade de adaptação às mudanças climáticas.

Palavras chaves: precipitação costeira, produtividade costeira, crescimento de peixe, previsão de capturas, gestão de pescarias.

\section{INTRODUCTION}

The Mozambique coast is rich in marine species diversity and has a relatively high fish production. The estimated potential of the fish in Mozambique is about 310,000 tons per year (Hoguane \& Pereira, 2003). The estimated overall marine fish landings varied between 115,000 and 140,000 tons per year during the period 2000 and 2004, and the artisanal fisheries contributed with about $87 \%$ of the total landings (Jacquet \& Zeller, 2007), with an annual value of over USD 50 million, almost all of which is traded in national markets.

The artisanal fisheries involve on average about 70,000 to 100,000 fishermen and fish collectors per year, who operate in coastal waters using canoe and small boats, and a variety of fishing gear including bottom trawls, beach seines, gillnets, hand-lines, traps and spears (Hoguane et al., 2002). There is large proportion of women and children involved mainly in fish collection, processing and commercialization (Jacquet \& Zeller, 2007). Thus, the artisanal fisheries contribute significantly to food security and nutritional needs of coastal communities in Mozambique.

Sustainability of this important resource is an issue of major concern in a country where the livelihood of the majority of population and the country's economic development depend largely on the exploitation and export of natural resources. In order to adopt sustainable management measures of the fisheries resources there is a need to understand the factors that determines their distribution and availability, apart from fishing effort. It should be noted that quite a number of studies have shown that management measures based solely on controlling effort are not effective (Hoguane et al., 2002) and call for the need of adoption of the Ecosystem Based Fisheries Management approach, a new management concept that considers integration of a set of interactions within the ecosystem that drivers the fish and fisheries production namely: biophysical, exploitative and trophodynamic drivers into management strategies (Garcia et al., 2003), aiming at sustaining the ecosystems and the services they provide. Biophysical drivers include rainfall and river runoff. A number of studies have used empirical models to examine the relationships between fishery production (as yield or catch) and precipitation (Welcomme, 1985; Garcia \& Le Reste, 1981) which are potentially useful decision supporting tools. Meynecke et al. (2006) examined the effect of rainfall on estuarine fish production in Queensland, Australia and found that more than $30 \%$ of Queensland's total fish catch variation can be explained by rainfall. Conway et al. (2005) examined the effects of rainfall on the natural-resources management in East Africa, including inland fisheries; they discussed the complex interactions between climate, environment and society in the region and highlighted the implications for natural-resources management. This management approach proves to be more effective than more holistic methods of fisheries management (Larkin, 1996). The rationale behind the positive relationship between freshwater input and coastal productivity lies in the fact that freshwater exports sediments and nutrients into the coastal water which in turn provide shelter and food to fish species at their earlier stage of life, increasing their survival rate and growth (Gammelsrød, 1992; Meynecke et al., 2006; Ayub, 2010).

Most of the studies on fish population and fisheries in Mozambique are related essentially to fisheries ecology and stock assessment. De Boer et al. (2001) examined the impact of the artisanal fishery activities on the benthic fishes and observed a reduction in the species composition and the catch rates as a result of increased fishing effort, in the intertidal flats of Inhaca Island, Mozambique. The effect of the environmental factors in the availability of fisheries resources in Mozambique have been seldom considered, apart from the few studies on the role of the Zambezi river runoff and the abundance of shallow water shrimp in Sofala Bank (Gammelsrød, 1992). The present paper analyses the relationship between freshwater input, through the coastal rainfall draining into coastal waters, and artisanal fish production in coastal area of northern Mozambique (Figure 1). The artisanal fish abundance was measured by the total annual catch, the fishing effort was measured by the number of active fishing gears and the freshwater input was measured by the rainfall observed at the meteorological station of Angoche. The hypothesis that the freshwater input influences positively the abundance of coastal fisheries, as observed by several authors in other locations (Gammelsrød, 1992, Meynecke et al., 2006; Ayub, 2010) was tested for the artisanal fisheries of northern Mozambique. This research may contribute to raising awareness on the importance of the environmental factors on the distribution and availability of the artisanal fisheries resources, and subsequently on the need to be taken into account in the management policies in Mozambique. 


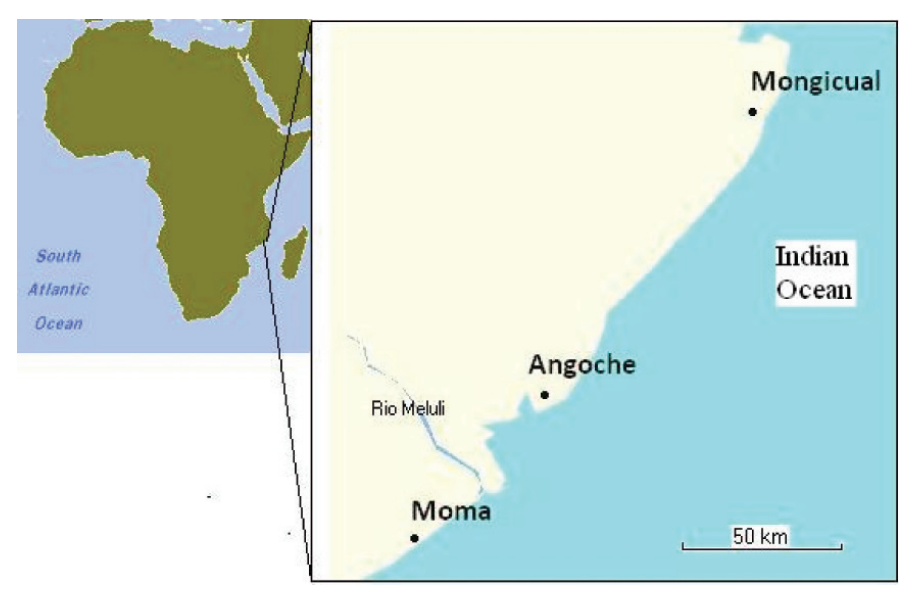

Figure 1. Map of the study area - the artisanal fishing centres of the districts of Moma, Angoche and Mongicual, in Northern Mozambique.

Figura 1. Mapa da área de estudo-centros de pesca artesanal nos distritos de Moma, Angoche e Mongicual, no norte de Moçambique.

\section{STUDY AREA}

The present study refer to the landings of artisanal fisheries observed in the coastal districts of Moma, Angoche and Mongicual and the rainfall observed at the Meteorological station of Angoche (Figure 1). This is one of the most productive coastal zones of Mozambique. The productivity is due to two major sources of nutrients: the coastal based sources through the freshwater input and the marine sources through shelf break upwelling.

The northern Mozambique has a tropical rain savannah climate, with two distinct seasons: winter or dry and summer or wet seasons. The average annual precipitation is about $1,200 \mathrm{~mm}$. The rainfall is mainly restricted to the warm season November to April. The winds are influenced by the equatorial low pressure zone with a NE and SW monsoon winds in the summer and winter, respectively (Hoguane \& Pereira, 2003). There are no major rivers draining into the coastal area, hence the freshwater input into the coastal waters is mainly due to local rain.

The topography of the area is characterized by narrow shelf, fringed by the coralline islands or coral banks. The shelf slope is sharply steepen and dominated by south going Mozambique Current at the outer edge and north going counter-current on the shelf (Sætre \& Jorge da Silva, 1982). There is significant upwelling on the slope driven by topography and seasonal monsoon winds (Machaieie, 2009). The tides are semi-diurnal with the tidal range varying from about 0.5 to $3 \mathrm{~m}$ during neap and spring tides, respectively.

\section{MATERIALS AND METHODS}

The study of the effect of the rainfall in the artisanal fish production in northern Mozambique was based in the artisanal catch statistics from 1998 to 2008 (Table 1).

Monthly artisanal catches recorded in three following centres of artisanal fisheries: Mongicual, Angoche and
Table 1. Rainfall recorded at Angoche meteorological station and catch statistics of the artisanal coastal fisheries in the Artisanal centres of Mongicual, Angoche and Moma, Northern Mozambique.

Tabela 1. Precipitaçâo registada na estação meteorológica de Angoche e estatísticas das capturas da pesca artesanal nos distritos de Mongicual, Angoche e Moma, no norte de Moçambique.

\begin{tabular}{rrrr}
\hline \multicolumn{1}{l}{ Year } & $\begin{array}{c}\text { Rainfall } \\
(\mathbf{m m})\end{array}$ & $\begin{array}{c}\text { Catch } \\
\text { (Tons) }\end{array}$ & $\begin{array}{c}\text { Effort } \\
\text { (No of fishing gear) }\end{array}$ \\
\hline 1995 & 952 & & \\
\hline 1996 & 1497 & & \\
\hline 1997 & 1361 & & 81522 \\
\hline 1998 & 769 & 15821 & 75764 \\
\hline 1999 & 773 & 11038 & 26627 \\
\hline 2000 & 1365 & 3929 & 78291 \\
\hline 2001 & 1137 & 4620 & 85151 \\
\hline 2002 & 1091 & 5658 & 84518 \\
\hline 2003 & 1065 & 7804 & 85292 \\
\hline 2004 & 942 & 5249 & 73408 \\
\hline 2005 & 718 & 2857 & 65793 \\
\hline 2006 & 1050 & 2910 & 59249 \\
\hline 2007 & 614 & 2549 & 66597 \\
\hline 2008 & 604 & 4217 & \\
\hline
\end{tabular}

Moma, by National Institute of Fisheries Research were used. The data was collected by samplers in each fishing centre, three days a week. During the sampling period a number of boats and of fishing gears used in the day was recorded and a random sample of 10 percent of the catch was selected for fish composition and biometric data analysis. The overall monthly catch in a fishing centre was estimated considering the average daily catch and average number of boats and of active fishing gears recorded during the sampling periods, and 21 days, an average number of fishing days a month, based on the census carried by IDPPE in 2004. The mostly caught groups of fish are presented in Table 2, and were obtained from the catch statistics.

Since the fishing effort was determined by the number of active gears, , with no indication of the fishing duration, and so unreadable fishing effort, then the total catch was used as a measure of fish production instead of catch per unit effort (CPUE). Hence, the total annual catch of the artisanal fisheries was linearly correlated with the annual rainfall recorded in Angoche, using MatLab, version R2007B. Four correlations were performed as follows: total annual catch with the rainfall (i) recorded in the same year, and with the rainfall (ii) lagged one year, (iii) lagged two years and (iii) lagged three years. 
Table 2. Dominant fish families caught by artisanal fisheries in Mongicual, Angoche and Moma during the period 1998-2008.

Tabela 2. Principais famílias que compóe as capturas no periodo de 1998-2008, nos distritos de Mongicual, Angoche e Moma.

\begin{tabular}{lcc}
\hline \multicolumn{1}{c}{ Family } & $\begin{array}{c}\text { Total catch (Tons) } \\
(\mathbf{1 9 9 8 - 2 0 0 8 )}\end{array}$ & $\begin{array}{c}\text { Percentage } \\
(\mathbf{0})\end{array}$ \\
\hline Engraulididae & 11266 & 15 \\
\hline Carangidae & 6422 & 9 \\
\hline Clupeidae & 5680 & 8 \\
\hline Leiognathidae & 4239 & 6 \\
\hline Trichiuridae & 4181 & 6 \\
\hline Scombridae & 3654 & 5 \\
\hline Sergestidae & 3618 & 4 \\
\hline Pomatomidae & 3137 & 4 \\
\hline Sciaenidae & 2771 & 4 \\
\hline Haemulidae & 2607 & 3 \\
\hline Mulidae & 2373 & 2 \\
\hline Siganidae & 1316 & 5 \\
\hline
\end{tabular}

\section{RESULTS AND DISCUSSION}

The artisanal fishing catch and rainfall data are presented in Table 1. The highest rainfall was $1,497 \mathrm{~mm}$, observed in 1996 and the lowest was $718 \mathrm{~mm}$, observed in 2005 . In 1998 there was a reduction in rainfall to $769 \mathrm{~mm}$, and further increase to $1,365 \mathrm{~mm}$ and $1,137 \mathrm{~mm}$ was observed in the years 2000 and 2001, respectively. The highest catch was 15,821 tons, observed in 1998 and the lowest was 2,549 tons, observed in 2007. A drop in catch to 3,929 tons was observed in 2000. Finally, in 2002 and 2003 there was further increase in catches to 5,658 tons and 7,804 tons, respectively.

The results of the correlation analyses are presented in Table 3. A positive and significant correlation between the rainfall and the artisanal total catch was found only with two years lag between the rainfall and the total catch (Table 3, Figure 2). This result is consistent with the findings of Quińones \& Montes (2001) on their studies of the relationship between freshwater input into the coastal zone and the historical landings of the benthic/demersal fish in central-south Chile.

There was no significant correlation found between the CPUE and rainfall and neither between the catches and the fishing effort. This could indicate that the availability of fish does not depend on the fishing effort or the measure of effort is not realistic, since it is given solely by the number of active gears, and there is no indication of the size, neither the time of application of these gears.

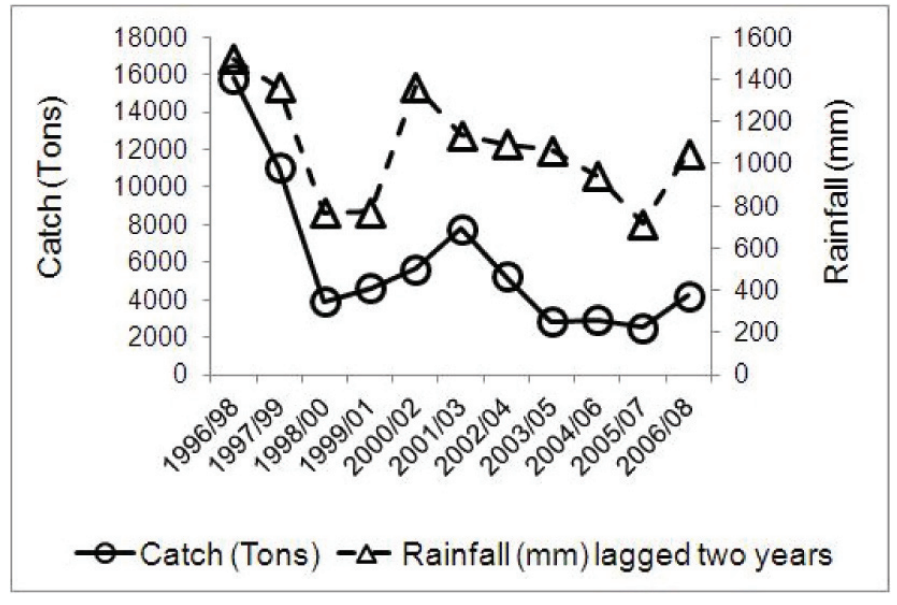

Figure 2. Time series of the annual artisanal total catch in Mongicual, Angoche and Moma with the annual rainfall recorded at Angoche lagged two years.

Figura 2. Series temporais anuais das capturas totais nos distritos de Mongicual, Angoche e Moma e precipitação anual registada em Angoche com desfasamento de dois anos.

Table 3. Result of correlation between total catch and rainfall, for the period 1996 to 2008, with different time lags between the rainfall and the catches $(\mathrm{n}=12)$.

Tabela 3. Resultados da correlação entre as capturas totais e a precipitação para os anos de 1996 a 2008, com diferentes desfasamentos entre a precipitação e as capturas $(n=12)$.

\begin{tabular}{ccc}
\hline Lag (years) & $\mathbf{r}$ & $\mathbf{p}$ \\
\hline 0 & -0.141 & 0.678 \\
\hline 1 & 0.388 & 0.238 \\
\hline 2 & 0.786 & 0.004 \\
\hline 3 & 0.225 & 0.506 \\
\hline
\end{tabular}

The positive correlation between the rainfall and productivity of coastal fisheries may be explained by the fact that the coastal rainfall stimulates the nutrient export into the coastal waters through the coastal drainage basins and adjoining mangrove swamps freshwater, which provides food for fish as explained by Gammelsrød (1992), Meynecke et al. (2006) and Ayub (2010). Also the freshwater input through the coastal drainage basin is associated with sediment load and relatively high turbidity in the coastal waters, providing suitable shelter for the fish larvae and juveniles from the predators. The two-year time lag at which the significant correlation was found may be explained by the fact that most caught fish groups such as Engraulididae, Clupeidae and Leiognathidae, have longevity of 2 to 4 years (Cabanban, 1991; Nelson, 1984; Whitehead et al., 1988) and most of the families such as Carangidae attain size caught by artisanal fishing gears at 2 years of age (Nelson, 1984). Considering the fact that freshwater contributes to the survival rate of 
larvae and juveniles as explained by Ayub (2010), then the effect of abundant freshwater into the fisheries would be felt few years later after recruitment, which is in agreement with Meynecke et al. (2006) who found correlation between total catch of fish with one to two years lagged response to rainfall events in Queensland. Thus, the annual artisanal fish catches in Northern Mozambique may be predicted two years ahead based on the rainfall in the area. A linear regression analysis predicting the total annual catch (tons) two years ahead the observed annual rainfall $(\mathrm{mm})$ was performed (Figure 3), and yield the following equation:

\section{Catch $=12.32 *$ Rainfall -7122}

This result is particularly important as it establishes the relationship between the fish production and the climate variables, and considering the fact that rainfall pattern is likely to change with global climate change, and then the impact of climate change in the artisanal fisheries of northern Mozambique can be foreseen. Several studies relating ENSO events in the Pacific and rainfall in southern Africa have indicted that El Niño events correspond to rainfall deficit (Rasmussen, 1987) and, conversely, heavy rains are associated to cold episode ofENSO (LaNiña) (Ogallo, 1987; Rasmussen, 1991; Glantz et al., 1997). Climate change scenario predicts an increase in the frequency of ENSO warm phases, thus the climate of southern Africa, where Mozambique is located, will be hotter and drier in the future than it is today; the annual regional precipitation is expected to reduce by 10 percent (Ragab \& Prudhomme, 2002). Consequently, the freshwater and nutrient inputs into the coastal waters will be reduced and so, the fish production. Further, according to the UNEP Africa environmental outlook report (UNEP, 2006) the climate change may cause irregular rainfall and draught patterns, and an event of high rainfall or extreme draught outside the seasons may conflict with the fish life cycle, resulting in reduced fish production.

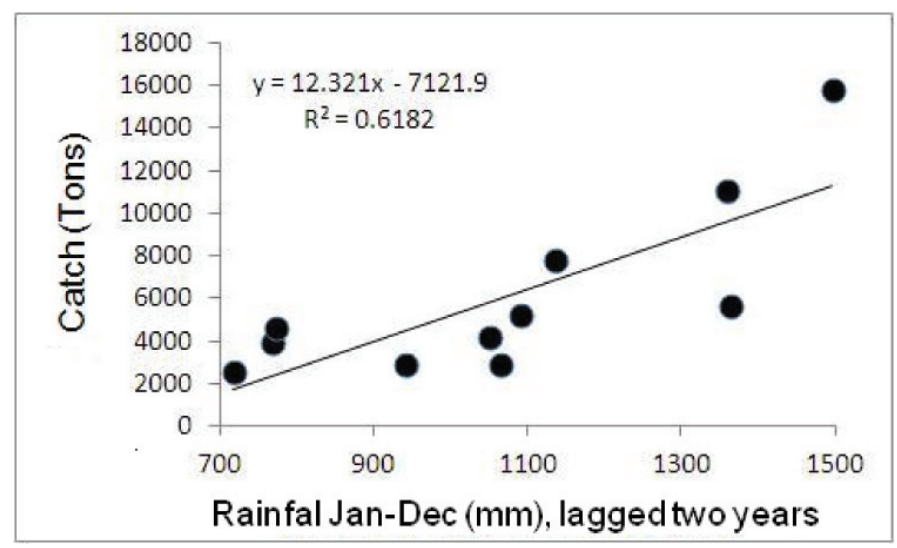

Figure 3. Regression analysis of artisanal annual catch (tons) and the total annual coastal rainfall (mm) lagged two years, from 1996 to 2008, for northern Mozambique.

Figura 3. Análise de regressão das capturas anuais da pesca artesanal (toneladas) e a precipitação anual ( $\mathrm{mm}$ ) com um desfasamento de dois anos, desde 1996 a 2008, para a zona costeira do norte de Moçambique.

\section{CONCLUSIONS}

From the present study it can be concluded that rainfall, in the coastal basin, can increase the productivity of the coastal waters, and hence of the coastal fisheries, since it exports nutrients that enrich and generate new production in coastal waters. On the other hand, the associated sediment load and turbidity provide shelter for the juveniles against predators in the adjoining mangrove swamps, thus providing a suitable survival and growth conditions of the fish species. However, the impact of the rainfall in the fisheries is felt when the fish attain commercial size, which depending on the life cycle and growth rate of the species it can be few yeas after the rain. For the case of the Northern Mozambique, the impact of the rainfall in the artisanal fisheries catches is felt two years later, which implies that most of the commercial fish species attain commercial size within two years of their life cycle. This result reiterates the role of the freshwater drained from the coastal zone in enhancing the productivity of the coastal waters and enables prediction of the artisanal fish catches as a function of rainfall, two years ahead, in Northern Mozambique.

\section{ACKNOWLEDGEMENT}

The artisanal catch and fishing effort data were provided by the National Institute of Fisheries Research. The rainfall data was provided by the National Institute of Meteorology.

\section{REFERENCES}

Ayub, Z. (2010) - Effect of Temperature and Rainfall as a Component of Climate Change on Fish and Shrimp Catch in Pakistan. The Journal of Transdisciplinary Environmental Studies (ISSN 1602-2297), 9(1):1-9, Roskilde, Denmark. Available on-line: http://www. journal-tes.dk/vol_9_no_1__page_15/no\%203\%20 \%20Edinger\%20og\%20Martin\%20\%28high\%29.pdf.

Cabanban, A.S. (1991) - The dynamics of Leiognathidae in tropical demersal ichthyofaunal community. 262 p., Dissertação de Doutorado, James Cook University of North Queensland, North Queensland, Australia. Não Publicado.

de Boer, W.F; van Schie, A.M.P.; Jocene, D.F., Mabote, A.B.P.; Guissamulo, A. (2001) - The impact of artisanal fishery on a tropical intertidal benthic fish community. Environmental Biology of Fishes. 61(2):213 -229. DOI:10.1023/A:1011043510100.

Conway, D.; Allison, E.; Felstead, R.; Goulden, M. (2005) Rainfall variability in East Africa: implications for natural resources management and livelihoods. Philosophical Transactions of the Royal Society A, 363:49-54. DOI:10.1098/rsta.2004.1475.

Gammelsrød, T. (1992). Variation in shrimp abundance on the Sofala Bank, Mozambique, and its relation to the Zambezi River runoff. Estuarine, Coastal and Shelf Science. 35(1):91-103. DOI: 10.1016/S02727714(05)80058-7.

Garcia, S.; Le Reste, L. (1981) - Life cycles, dynamics, exploita and management of coastal penaeid shrimp stocks. FAO Fisheries Technical Paper No. 203, Food and Agriculture Organization of the United Nations, Rome, Italy. ISBN: 9251010692. 
Garcia, S. M.; Zerbi, A.; Aliaume, C.; Do Chi, T.'Lasserre, G. (2003) - The ecosystem approach to fisheries: issues, terminology, principles, institutional foundations, implementation and outlook. FAO Fisheries Technical Paper No. 443, Food and Agriculture Organization of the United Nations, Rome, Italy. ISBN: 9251049602 . Available on-line: http://ocean.floridamarine.org/efh_coral/pdfs/Ecosystem_ Approaches_to_Fisheries_FAO.pdf.

Glantz, M.H.; Betsill, M.; Crandall, K. (1997) - Food security in southern Africa. Assessing the use and value of ENSO information. Report on NOAA Proposal GC95017, 142p., National Center for Atmospheric Research, ESIG/NCAR, Boulder, CO, USA. Available on-line: http://www.isse.ucar.edu/sadc/index.html.

Hoguane, A.M.; Pereira, M.A.M. (2003) - National Report: Marine biodiversity in Mozambique - the known and the unknown. In: C. Decker, C. Griffiths, K. Prochazka, C. Ras \& A. Whitefield (eds.), Marine Biodiversity in Sub-Saharan Africa: the known and the unknown, pp.138-155, Cape Town, South Africa. Available online: http://s3.amazonaws.com/zanran_storage/coml.us/ ContentPages/116244868.pdf

Hoguane, A.M.; Motta, H.; Lopes, S.; Menete, Z. (2002) - Mozambique National Report on integrated problem analysis. Development and protection of the coastal and marine environment in sub-Saharan Africa". 125p, GEF MSP Sub-Saharan Africa Project (GF/6010-0016), Maputo, Mozambique. Não Publicado.

Jacquet, J.L.; Zeller, D. (2007) - National conflict and fisheries: Reconstructing marine fisheries catches for Mozambique. In: D. Zeller \& D. Pauly (eds.), Reconstruction of marine fisheries catches for key countries and regions (1950-2005). Fisheries Centre Research Reports (ISSN: 1198-6727) 15(2):35-47, Fisheries Centre, University of British Columbia, Vancouver, Canada. Available on-line: http://www.seaaroundus.org/researcher/dpauly/ PDF/2007/Books\&Chapters/ 